2017-06-30

The interdisciplinary use of

"overpressure"

\title{
Peacock, DCP
}

http://hdl.handle.net/10026.1/9611

10.1016/j.jvolgeores.2017.05.005

Journal of Volcanology and Geothermal Research

Elsevier BV

All content in PEARL is protected by copyright law. Author manuscripts are made available in accordance with publisher policies. Please cite only the published version using the details provided on the item record or document. In the absence of an open licence (e.g. Creative Commons), permissions for further reuse of content should be sought from the publisher or author. 


\section{Accepted Manuscript}

The interdisciplinary use of "overpressure"

D.C.P. Peacock, M.W. Anderson, A. Rotevatn, D.J. Sanderson, E. Tavarnelli

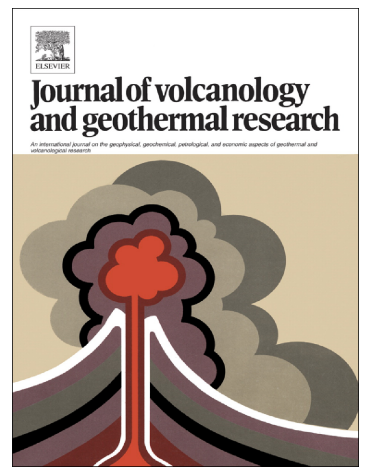

PII: S0377-0273(17)30023-9

DOI: doi: 10.1016/j.jvolgeores.2017.05.005

Reference: VOLGEO 6090

To appear in: Journal of Volcanology and Geothermal Research

Received date: $\quad 6$ January 2017

Revised date: $\quad 5$ May 2017

Accepted date: $\quad 6$ May 2017

Please cite this article as: D.C.P. Peacock, M.W. Anderson, A. Rotevatn, D.J. Sanderson, E. Tavarnelli , The interdisciplinary use of "overpressure", Journal of Volcanology and Geothermal Research (2017), doi: 10.1016/j.jvolgeores.2017.05.005

This is a PDF file of an unedited manuscript that has been accepted for publication. As a service to our customers we are providing this early version of the manuscript. The manuscript will undergo copyediting, typesetting, and review of the resulting proof before it is published in its final form. Please note that during the production process errors may be discovered which could affect the content, and all legal disclaimers that apply to the journal pertain. 


\title{
The interdisciplinary use of "overpressure"
}

D.C.P. Peacock ${ }^{1}{ }^{*}$, M.W. Anderson ${ }^{2}$, A. Rotevatn ${ }^{1}$, D.J. Sanderson ${ }^{3}$ and E. Tavarnelli ${ }^{4}$

${ }^{1}$ Department of Earth Science, University of Bergen, Allégaten 41, 5007 Bergen, Norway

${ }^{2}$ School of Geography, Earth and Environmental Sciences, University of Plymouth, Plymouth PL4 8AA, UK

${ }^{3}$ Engineering and the Environment, University of Southampton, Highfield, Southampton, SO17 1BJ, UK

${ }^{4}$ Dipartimento di Scienze Fisiche della Terra e dell'Ambiente, Università di Siena, I-53100, Siena, Italy

* Corresponding author. E-mail: hermangedge@gmail.com

\begin{abstract}
Overpressure is a polysemic word that has a variety of meanings within and across different disciplines. This is likely to be a particular problem in analysis of geothermal resources, where reservoir engineers, volcanologists and structural geologists may each confidently use overpressure but mean different things. We suggest that, to avoid confusion, the term should be carefully and accurately defined whenever used. We also suggest that other, less ambiguous terms be used, such as supra-hydrostatic fluid pressure when fluid pressure exceeds that expected in a column of water at that depth, and supra-lithostatic fluid pressure for the situation in which fluid pressure exceeds the overburden.
\end{abstract}

Keywords: overpressure; polyseme; structural geology; volcanology; geothermal 


\section{Introduction}

Fluid pressure and especially overpressure are important for a wide variety of reasons, including the following:

- Accurate prediction and measurement of fluid pressures can be critical for the safe and successful drilling of hydrocarbon and other wells (e.g. Taras'ev and Simkin 1969;

Gaarenstroom et al., 1993). For example, overpressure is related to sediment remobilisation (e.g. Jolly and Lonergan, 2002), seal risk and breaching of hydrocarbon traps (e.g. Ingram and Urai, 1999), fluid-pressure driven deformation (e.g. Cartwright, 1994), and to the danger of blowout during drilling (e.g. Hickman et al., 2012).

- Overpressure is important in controlling volcanism (e.g. Fudali and Melson, 1971) and emplacement of igneous intrusions (e.g. Kusumoto et al., 2013a).

- Pore fluid pressure $\left(\mathrm{P}_{\mathrm{F}}\right.$. See Table 1 for symbols used) plays a critical role in many structural processes. For example, Hubbert and Rubey (1959) argue that thrust sheets slide on layers of overpressured fluids that reduce friction.

- Overpressured fluids have been cited as contributing to earthquakes (e.g. Blanpied et al., 1992).

In spite of their importance, terms relating to fluid pressure and overpressure are commonly used differently within and between disciplines. We argue that overpressure is now so polysemic that is must be carefully and accurately defined whenever used to avoid confusion, especially in such interfaces between disciplines as the analysis of geothermal resources. Socrates is quoted as having said that "the beginning of wisdom is the definition of terms" (e.g. Hollingsworth, 2015). The philosophy that the terms used must be carefully defined and precisely used has been a foundation of academic research. 


\begin{tabular}{|l|l|}
\hline$\sigma_{3}$ & Least compressive stresses \\
\hline$\sigma_{\mathrm{V}}$ & Vertical stress, also called lithostatic stress or overburden \\
\hline $\mathrm{P}_{\mathrm{F}}$ & Pore fluid pressure \\
\hline $\mathrm{P}_{\mathrm{H}}$ & (Hydrostatic) fluid pressure of an equivalent free column of water \\
\hline $\mathrm{P}_{\mathrm{M}}$ & Magma pressure \\
\hline $\mathrm{P}_{\mathrm{O}}$ & "Magma overpressure" (Elshaafi and Gudmundsson, 2016) \\
\hline $\mathrm{P}_{\mathrm{FRACT}}$ & Fracture pressure, in which $\mathrm{P}_{\mathrm{F}}>\sigma_{3}+$ rock strength \\
\hline$\rho_{\mathrm{R}}$ & Host rock density \\
\hline$\rho_{\mathrm{M}}$ & Magma density \\
\hline $\mathrm{g}$ & Acceleration due to gravity \\
\hline $\mathrm{h}$ & Depth \\
\hline$\sigma_{\mathrm{D}}$ & Differential stress at the level of interest \\
\hline$\sigma^{\prime}$ & Effective stress ( $\sigma$ - P $\mathrm{F})($ e.g. Hubbert and Rubey, 1959) \\
\hline$\sigma_{3}^{\prime}$ & Least effective stress \\
\hline
\end{tabular}

Table 1. Symbols used in this paper. 
The aims of this paper are to show some of the different uses and definitions used for overpressure, to usage, and to suggest more precise terms for certain overpressure conditions. The aim is not to give an account of fracture mechanics, including the relationships between fluid pressure and fractures, which is dealt with in various textbooks (e.g. van der Pluijm and Marshak, 2010; Fossen, 2012). The aims of this paper are to discuss and clarify the different uses of overpressure.

\section{Different uses of overpressure}

This section illustrates the variety of uses to which the term overpressure is applied.

\section{General definitions of overpressure}

Overpressure, in this context, is defined by the Oxford English Dictionary (Simpson and Weiner, 1989) as "the difference between the (highest) instantaneous pressure at a point subjected to a shock wave and the ambient atmospheric pressure", with first usage credited to Goldstine and Von Neumann (1955). Similarly, overpressure is defined by the MerriamWebster Dictionary (http://www.merriam-webster.com/dictionary/overpressure) as "pressure significantly above what is usual or normal". Whilst these appear to be precise and useful definitions, they are vague enough to have been used in different ways by different researchers

\section{Use of overpressure outside of geosciences}

The word overpressure is used in a wide range of disciplines, including acoustics (e.g. Sapozhnikov et al., 2002), aerospace science (e.g. Hammitt, 1961), astronomy (e.g. Jog and Das, 1992), biology (e.g. de Rycke, 1966), education (e.g. Robertson, 1972), engineering (e.g. Selig et al., 1960), medical sciences (e.g. Harpöth and Gad, 1938; Mayorga, 1997), physics 
and chemistry (e.g. Potts and Pearson, 1966) and psychology (e.g. Bateman, 1896-7; Rubin et al., 2014). We do not give definitions of overpressure as used in each of these subject areas, but present these examples simply to illustrate the variety of situations in which the word is used.

Overpressure in the hydrocarbon industry

The importance of overpressure is reflected in its consistent usage in the hydrocarbon industry, where overpressure is defined as the condition in which $\mathrm{P}_{\mathrm{F}}$ exceeds the value that would be expected for that depth in a water column, i.e. above hydrostatic pressure $\left(\mathrm{P}_{\mathrm{H}}\right.$, e.g. Fertl and Chilingarian, 1989; Caillet et al., 1997; Swarbrick and Schneider, 1999; Yardley and Swarbrick, 2000; Bowers, 2002; Bjørlykke et al., 2010) (Figure 1a). The situation in which $\mathrm{P}_{\mathrm{F}}$ is sufficient to cause fracturing is commonly termed fracture pressure $\left(\mathrm{P}_{\mathrm{FRAC}}\right)(\mathrm{e} . \mathrm{g}$. Morgenstern, 1962; Swarbrick and Lahann, 2016). This is commonly inferred to be the situation in which $P_{F}$ exceeds the least compressive stress $\left(\sigma_{3}\right)$ plus rock strength. $P_{F R A C}$ is commonly estimated in wells by leak-off tests (e.g. Couzens-Schultz and Chan, 2010). The fluids measured can be water, oil or gas, and these can occur in pore spaces and in fractures.

Overpressure can develop within sediments that are compacted during burial, as thermal expansion occurs, and as hydrocarbons are generated (e.g. Cobbold et al., 2013; Lahann and Swarbrick, 2011). Overpressure can also develop during uplift and erosion events as vertical stress $\left(\sigma_{\mathrm{V}}\right)$ is reduced but $\mathrm{P}_{\mathrm{F}}$ is maintained (e.g. Doré and Jensen, 1996; Corcoran and Doré, 2002). Overpressure is particularly likely to develop within sands that are compartmentalised by faults and impermeable shales (e.g. Bredehoeft et al., 1988). 
(a)

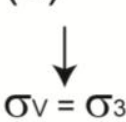

$\sigma^{\prime}{ }_{3}=$ compressive

$$
\sigma^{\prime} 3=
$$
tensile

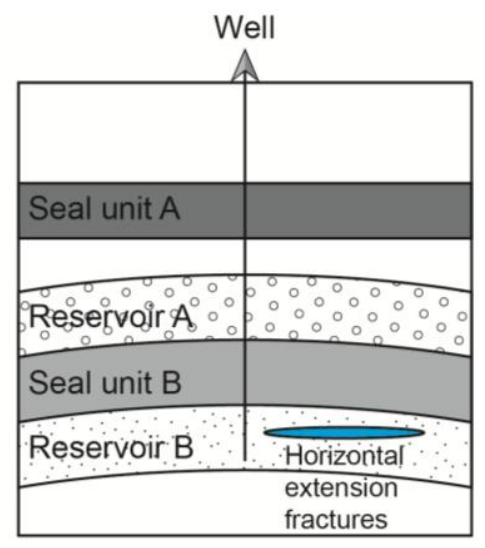

(c)<smiles>CC(C)(C)[O-]</smiles>

$\sigma^{\prime} 3=$ compressive

$$
\sigma^{\prime} 3=
$$
tensile
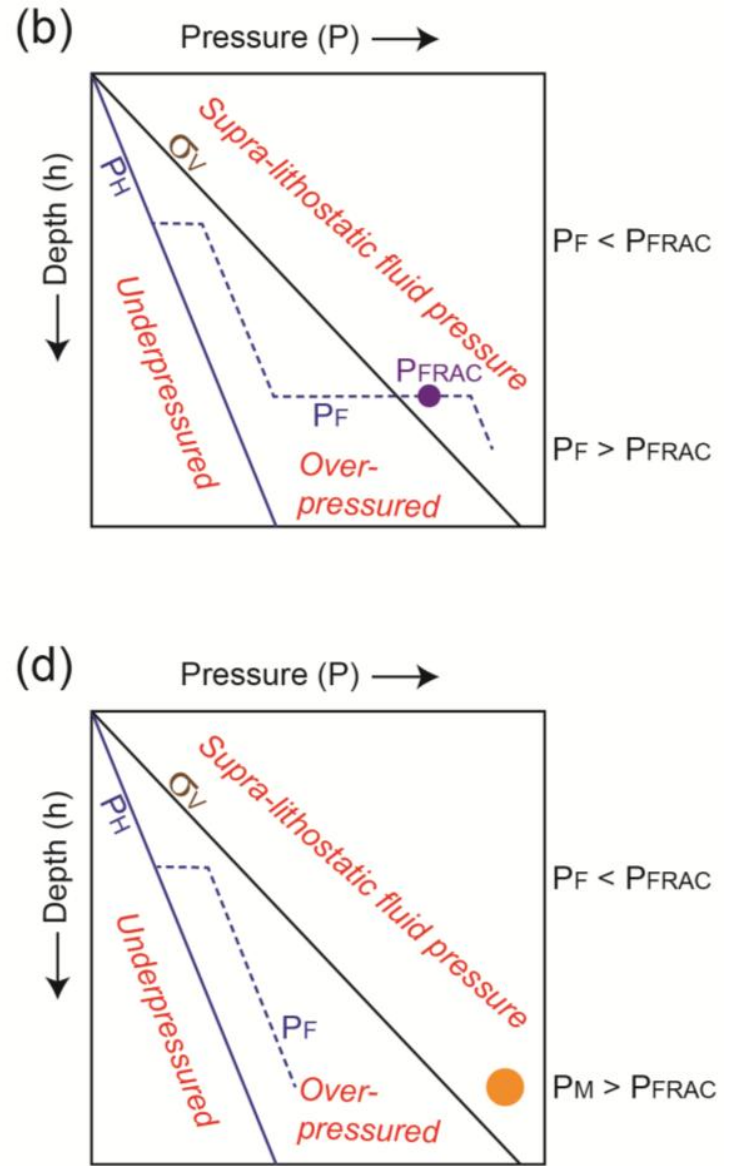

Figure 1. Schematic diagrams of fluid pressure, illustrating some of the different potential uses of overpressure. In these examples, the least compressive stress is vertical $\left(\sigma_{3}=\sigma_{\mathrm{V}}\right)$. (a) Schematic cross-section showing a well penetrating two seal units and two hydrocarbon reservoirs. (b) Graph of depth versus pressure for Figure 1(a). In reservoir $A, P_{H}<P_{F}<\sigma_{V}$, so the reservoir is overpressured, but is below the fracture pressure $\left(\mathrm{P}_{\mathrm{FRAC}}\right)$. In reservoir $\mathrm{B}, \mathrm{P}_{\mathrm{H}}<$ $\sigma_{\mathrm{V}}<\mathrm{P}_{\mathrm{F}}$, so it is both overpressured and supra-lithostatically pressured. $\mathrm{P}_{\mathrm{F}}>\mathrm{P}_{\mathrm{FRAC}}$, leading to the development of extension fractures. (c) Schematic cross-section showing a well penetrating a seal unit, a hydrocarbon reservoir and a sill. (d) Graph of depth versus pressure for Figure 1(c). In reservoir $\mathrm{A}, \mathrm{P}_{\mathrm{H}}<\mathrm{P}_{\mathrm{F}}<\sigma_{\mathrm{V}}$, so is overpressured, but is below the fracture pressure $\left(\mathrm{P}_{\mathrm{FRAC}}\right)$. At the sill, $\mathrm{P}_{\mathrm{H}}<\sigma_{\mathrm{V}}<\mathrm{P}_{\mathrm{M}}$, and $\mathrm{P}_{\mathrm{M}}>\mathrm{P}_{\mathrm{FRAC}}$, leading to sill propagation. 


\section{Overpressure in volcanology}

Most commonly, magma or related gasses are the fluids of interest in the subject of volcanology, these occurring in magma chambers or other intrusions. In spite of the importance of overpressure, the term appears to be used in various different ways in the discipline of volcanology (e.g. within papers published in the Journal of Volcanology and Geothermal Research, including: Fudali and Melson, 1971; Melnik et al., 2005; Davies et al., 2011; Kusumoto et al., 2013a; Elshaafi and Gudmundsson, 2016). For example:

- Kusumoto et al. (2013a) define overpressure as the magmatic pressure in a dyke minus the least principal compressive stress $\left(\sigma_{3}\right)$ acting on the dyke walls.

- Elshaafi and Gudmundsson (2016) define magma overpressure $\left(\mathrm{P}_{\mathrm{O}}\right)$ in a dyke as:

$$
P_{O}=\left(P_{M}-\sigma_{V}\right)+\left(\rho_{R}-\rho_{M}\right) g h-\sigma_{D}
$$

where $\mathrm{P}_{M}=$ magma pressure, $\rho_{R}=$ host rock density, $\rho_{M}=$ magma density, $g=$ acceleration due to gravity, $h=$ depth, and $\sigma_{D}=$ differential stress at the level of interest (Table 1). This appears to imply the conditions under which the magma exceeds $\sigma_{3}$, leading to sill propagation if $\sigma_{3}$ is sub-vertical, or dyke propagation if $\sigma_{3}$ is sub-horizontal. This can approximate to $\mathrm{P}_{\mathrm{FRAC}}$, as used in the hydrocarbon industry (Figure 1b).

- Overpressure is widely used to mean gas pressures that are high enough to cause explosive volcanic eruptions (e.g. Fudali and Melson, 1971; Melnik et al., 2005; Burgisser et al., 2011), or even trigger earthquakes (Giammanco et al., 2008).

- Overpressure is apparently used by Trasatti et al. (2005) to indicate fluid pressures above typical hydrostatic pressures, which would be similar to its usage in the hydrocarbon industry (e.g. Caillet et al., 1997; Swarbrick and Schneider, 1999; Yardley and Swarbrick, 2000; Bowers, 2002; Bjørlykke et al., 2010). 
- Some of the literature on mud volcanoes appears to use overpressure in the same way as the hydrocarbon industry and structural geology (e.g. Davies et al., 2011), i.e. when $\mathrm{P}_{\mathrm{F}}>$ $\mathrm{P}_{\mathrm{H}}$.

- Some authors use, and even model, overpressure without a clear definition (e.g. Hautmann et al., 2009; Mazzini et al., 2009; Shirzaei et al., 2013; Kavanagh et al., 2015).

Use of overpressure in volcanology is therefore much less consistent than usage in the hydrocarbon industry.

Overpressure in structural geology

Any fluid in rock may be of interest in structural geology, including water, hydrocarbons, $\mathrm{CO}_{2}$ and magma. These fluids may occur in pore spaces, fractures or in other spaces in rock. Overpressure is predominantly used within structural geology (e.g. as published in Tectonophysics and the Journal of Structural Geology) in the same way as in the hydrocarbon industry. Overpressure is thus defined as the condition in which $\mathrm{P}_{\mathrm{F}}>\mathrm{P}_{\mathrm{H}}$, i.e. it exceeds the hydrostatic pressure of an equivalent free column of water (e.g. Bolton et al., 1998; Sibson, 2004; Mourgues and Cobbold, 2006; Mazzarini and Isola, 2007; Lacoste et al., 2011, fig. 1; Lacoste et al., 2012; Cobbold et al. 2013; Suppe, 2014; Mourgues et al., 2016) (Figure 1a). Less formally, however, structural geologists may infer that overpressure existed during deformation by the occurrence of such structures as horizontal veins, which form when $\mathrm{P}_{\mathrm{F}}$ exceeds the vertical stress $\left(\sigma_{\mathrm{V}}\right)$, showing that $\mathrm{P}_{\mathrm{F}}>\mathrm{P}_{\mathrm{H}}$ (e.g. Stoneley, 1983; Hillier and Cosgrove, 2002; Tavarnelli et al., 2004). This inference does not, however, mean that overpressure is actually defined as the condition in which $\mathrm{P}_{\mathrm{F}}>\sigma_{\mathrm{V}}$. Some authors use the term "driving pressure" to mean $P_{\text {FRAC }}$ (e.g. Pollard and Johnson, 1973; Renshaw and Pollard, 1994), and the importance of differential stress is acknowledged (e.g. Cox. 2010)... 
Definitions used in volcanology (e.g. Kusumoto et al., 2013a) sometimes get used in the structural geology literature. For example, Gudmundsson et al. (2012) define overpressure as "the difference between the total fluid pressure inside the fracture and the normal stress at that point" (also apparently used by Kusumoto et al., 2013b).

Two fundamental uses of the term "overpressure"

There therefore appear to be two fundamental differences in the usage of the term overpressure:

1. As a limit or threshold above which some physical change takes place, such as dyke opening or explosive volcanism.

2. As a measure of how much a pressure (stress) exceeds a standard value, such as hydrostatic or lithostatic stresses.

In both cases, there is a need to define the usage precisely and to use more precise, less ambiguous terms (see below).

\section{Geothermal energy as an example of the need for precise terminology}

The exploitation of geothermal energy in volcanic regions means that reservoir engineers, volcanologists and structural geologists will tend to need to collaborate. As with the hydrocarbon industry, safe and successful drilling of geothermal wells requires prediction and measurement of $\mathrm{P}_{\mathrm{F}}$, but in this case perhaps including $\mathrm{P}_{\mathrm{M}}$, so scientists from the different disciplines require a common understanding of what is meant by overpressure. Reservoir engineers and modellers working on geothermal energy appear to use overpressure in the same sense as in the hydrocarbon industry. For example, Dempsey et al. (2015) define overpressure as "pressure in excess of undisturbed formation pressure". Whilst this is 
compatible with the predominant usage in structural geology, it is different from several of the definitions in volcanology.

Figure 1(c) illustrates the potential differences between different definitions of overpressure in a geothermal reservoir. $\mathrm{P}_{\mathrm{F}}$ for the water in a hydrothermal system may exceed $\mathrm{P}_{\mathrm{H}}$ but be less than $\mathrm{P}_{\mathrm{FRAC}}$, whilst $\mathrm{P}_{\mathrm{M}}$ may exceed $\mathrm{P}_{\mathrm{FRAC}}$, leading the emplacement of igneous intrusions. To limit confusion, there is a need for clear, unambiguous definitions that all scientists working together will understand.

\section{Suggested alternative terms}

It would be advantageous to use unambiguous terms to avoid the potential for confusion. For example, fracture pressure (e.g. Morgenstern, 1962; Swarbrick and Lahann, 2016) may be used when $P_{F}$ is high enough to generate fractures. Similar terms that have been used in relation to volcanic activity include opening pressure (e.g. Ida, 1992) or eruption pressure (e.g. Morrissey et al., 2010). Similarly, supra-hydrostatic fluid pressure may be used when fluid pressure exceeds that expected in a column of water at that depth (e.g. Sibson, 1990), and supra-lithostatic fluid pressure (Sibson, 1992) may be used when $P_{F}>\sigma_{V}$ (Figure $1 d)$.

\section{Conclusions}

Overpressure has been cited as being important in a wide variety of processes in the geosciences, including hydrocarbon production, volcanism, faulting and seismic activity. The term overpressure is, however, a polyseme, being used in different ways by different researchers. For example, several different uses appear in the volcanology literature. This diversity of usage may cause confusion, especially where people from different disciplines have to collaborate, as in the exploitation of geothermal energy. It is therefore important that 
each usage of overpressure is precisely defined and carefully explained in relation to other stress components. We suggest that use of the following terms and definitions will give greater precision:

- Overpressure should be confined to the condition in which $\mathrm{P}_{\mathrm{F}}$ exceeds the value that would be expected for that depth in a water column (hydrostatic pressure), i.e. in the same way as is used in the hydrocarbon industry (e.g. Fertl and Chilingarian, 1989) and predominantly in structural geology (e.g. Bolton et al., 1998). Alternatively, supra-hydrostatic fluid pressure could be used when fluid pressure exceeds that expected in a column of water at that depth (e.g. Sibson, 1990).

- Fracture pressure $\left(\mathrm{P}_{\mathrm{FRAC}}\right)$ should be used for the condition in which $\mathrm{P}_{\mathrm{F}}$ is strong enough to cause fracturing. For example, extension fractures (including dykes and sills) will form when $\mathrm{P}_{\mathrm{F}}$ exceeds $\sigma_{3}$ and the rock strength (e.g. Swarbrick and Lahann, 2016).

- Supra-lithostatic fluid pressure should be used for the condition in which $\mathrm{P}_{\mathrm{F}}$ exceeds $\sigma_{\mathrm{V}}$ (Sibson, 1992). Sills will tend to develop under these conditions if the fluid is magma.

\section{References}

Bateman, F., 1896-7. On intemperance, consanguine marriages, and educational overpressure, as factors in the genesis of nerve disease and degeneration of the race. Medico-Legal Journal XIV, 443-454.

Bjørlykke, K., Jahren, J., Aagaard, P., Fisher, Q., 2010. Role of effective permeability distribution in estimating overpressure using basin modelling. Marine and Petroleum Geology 27, 1684-1691.

Blanpied, M.L., Lockner, D.A., Byerlee, J.D., 1992. An earthquake mechanism based on rapid sealing of faults. Nature 358, 574-576. 
Bolton, A.J., Maltman, A.J., Clennell, M.B., 1998. The importance of overpressure timing and permeability evolution in fine-grained sediments undergoing shear. Journal of Structural Geology 20, 1013-1022.

Bowers, G.L., 2002. Detecting high overpressure. The Leading Edge 21, 174-177.

Bredehoeft, J., Djevanshir, R.D., Belitz, K.R., 1988. Lateral fluid flow in a compacting sandshale sequence: South Caspian Basin. American Association of Petroleum Geologists Bulletin 72, 416-424.

Burgisser, A., Arbaret, L., Druitt, T.H., Giachetti, T., 2011. Pre-explosive conduit conditions of the 1997 Vulcanian explosions at Soufrière Hills Volcano, Montserrat: II.

Overpressure and depth distributions. Journal of Volcanology and Geothermal Research 199, 193-205.

Caillet, G., Judge, N.C., Bramwell, N.P., Meciani, L, Green, M., Adam, P., 1997.

Overpressure and hydrocarbon trapping in the Chalk of the Norwegian Central Graben. Petroleum Geoscience 3, 33-42.

Cartwright, J.A., 1994. Episodic basin-wide hydrofracturing of overpressured Early Cenozoic mudrock sequences in the North Sea Basin. Marine and Petroleum Geology 11, 587607.

Cobbold, P.R., Zanella, A., Rodrigues, N., Løseth, H., 2013. Bedding-parallel fibrous veins (beef and cone-in-cone): worldwide occurrence and possible significance in terms of fluid overpressure, hydrocarbon generation and mineralization. Marine and Petroleum Geology 43, 1-20.

Corcoran, D.V., Doré, A.G., 2002. Depressurization of hydrocarbon-bearing reservoirs in exhumed basin settings: evidence from Atlantic margin and borderland basins. In: Doré, A.G., Cartwright, J.A., Stoker, M.S., Turner, J.P., White, N. (eds). Exhumation of the 
North Atlantic Margin: Timing, Mechanisms and Implications for Hydrocarbon Exploration. Geological Society of London, Special Publication 196, 457-483.

Couzens-Schultz, B.A., Chan, A.W., 2010. Stress determination in active thrust belts: An alternative leak-off pressure interpretation. Journal of Structural Geology 32, 10611069.

Cox, S.F., 2010. The application of failure mode diagrams for exploring the roles of fluid pressure and stress states in controlling styles of fracture-controlled permeability enhancement in faults and shear zones. Geofluids 10, 217-233.

Davies, R., Manga, M., Tingay, M., Swarbrick, R., 2011. Fluid transport properties and estimation of overpressure at the Lusi mud volcano, East Java Basin (Tanikawa et al., 2010). Engineering Geology 121, 97-99.

de Rycke, P.H., 1966. The hydrostatic overpressure in Echinococcus granulosus cysts. Zeitschrift für Parasitenkunde 28, 14-15.

Dempsey, D., Kelkar, S., Davatzes, N., Hickman' S., Moos, D., 2015. Numerical modeling of injection, stress and permeability enhancement during shear stimulation at the Desert Peak Enhanced Geothermal System. International Journal of Rock Mechanics and Mining Sciences 78, 190-206.

Doré, A.G., Jensen, L.N., 1996. The impact of late Cenozoic uplift and erosion on hydrocarbon exploration: offshore Norway and some other uplifted basins. Global Planetary Change 12, 415-436.

Elshaafi, A., Gudmundsson, A., 2016. Volcano-tectonics of the Al Haruj Volcanic Province, Central Libya. Journal of Volcanology and Geothermal Research 325, 189-202.

Fertl, W.H., Chilingarian, G.V., 1989. Prediction of tectonically-caused overpressures by using resistivity and density measurements of associated shales. Journal of Petroleum Science and Engineering 3, 203-208. 
Fossen, H., 2010. Structural Geology. 2nd Edition. Cambridge University Press, Cambridge, pp. 510.

Fudali, R.F., Melson, W.G., 1971. Ejecta velocities, magma chamber pressure and kinetic energy associated with the 1968 eruption of arenal volcano. Bulletin Volcanologique $35,383-401$

Gaarenstroom, L., Tromp, R.A.J., de Jong, M.C., Brandenburg, A.M., 1993. Overpressures in the Central North Sea: implications for trap integrity and drilling safety. Geological Society, London, Petroleum Geology Conference 4, 1305-1313.

Giammanco, S., Palano, M., Scaltrito, A., Scarfi, L., Sortino, F., 2008. Possible role of fluid overpressure in the generation of earthquake swarms in active tectonic areas: the case of the Peloritani Mts. (Sicily, Italy). Journal of Volcanology and Geothermal Research $178,795-806$

Goldstine, H.H., Von Neumann, J., 1955. Blast wave calculation. Communications on Pure and Applied Mathematics 8, 327-353.

Gudmundsson, A., Kusumoto, S., Simmenes, T.H., Philipp, S.L., Larsen, B., Lotveit, I.F., 2012. Effects of overpressure variations on fracture apertures and fluid transport. Tectonophysics 581, 220-230.

Hammitt, A.G., 1961. The oscillation and noise of an overpressure sonic jet. Journal of the Aerospace Sciences 28, 673-680.

Harpöth, H., Gad, U., 1938. On pleural perforation in pulmonary tuberculosis. Character of the pleural exudate; diagnosis of the perforation of gas analysis. The British Journal of Tuberculosis 32, 228-234.

Hautmann, S., Gottsmann, J., Sparks, R.S.J., Costa, A., Melnik, O., Voight, B., 2009. Modelling ground deformation caused by oscillating overpressure in a dyke conduit at Soufrière Hills Volcano, Montserrat. Tectonophysics 471, 87-95. 
Hickman, S.H., Hsieh, P.A., Mooney, W.D., Enomoto, C.B., Nelson, P.H., Mayer, L.A., Weber, T.C., Moran, K., Flemings, P.B., McNutt, M.K., 2012. Scientific basis for safely shutting in the Macondo Well after the April 20, 2010 Deepwater Horizon blowout. Proceedings of the National Academy of Sciences of the United States of America 109, 20268-20273.

Hillier, R.D., Cosgrove, J.W., 2002. Core and seismic observations of overpressure-related deformation within Eocene sediments of the Outer Moray Firth, UKCS. Petroleum Geoscience 8, 141-149.

Hollingsworth, A., 2015. "The beginning of wisdom is the definition of terms" - Socrates. The Breast Journal 21, 119-120.

Hubbert, M. K., Rubey, W., 1959. Role of fluid pressure in mechanics of over-thrust faulting. Parts I and II. Bulletin of the Geological Society of America 70, 115-205.

Ida, Y., 1992. Width change of a planar magma path: implication for the evolution and style of volcanic eruptions. Physics of the Earth and Planetary Interiors 74, 127-138.

Ingram, G.M., Urai, J.L., 1999. Top-seal leakage through faults and fractures: the role of mudrock properties. In: Aplin, A.C., Fleet, A.J., Macquaker, J.H.S. (eds.) Muds and Mudstones: Physical and Fluid Flow Properties. Geological Society, London, Special Publications 158, 125-135.

Jog, C.J., Das, M., 1992. Starbursts triggered by central overpressure in interacting galaxies. The Astrophysics Journal 400, 476-483.

Jolly, R.J.H., Lonergan, L., 2002. Mechanisms and controls on the formation of sand intrusions. Journal of the Geological Society, London, 159, 605-617.

Kavanagh, J.L., Boutelier, D., Cruden, A.R., 2015. The mechanics of sill inception, propagation and growth: Experimental evidence for rapid reduction in magmatic overpressure. Earth and Planetary Science Letters 421, 117-128. 
Kusumoto, S., Geshi, N., Gudmundsson, A., 2013a. Aspect ratios and magma overpressures of non-feeder dikes observed in the Miyake-jima volcano (Japan), and fracture toughness of its upper part. Geophysical Research Letters 40, 1065-1068.

Kusumoto, S., Gudmundsson, A., Simmenes, T.H., Geshi, N., Philipp, S.L., 2013b. Inverse modeling for estimating fluid-overpressure distributions and stress intensity factors from an arbitrary open-fracture geometry. Journal of Structural Geology 46, 92-98.

Lahann, R.W., Swarbrick, R.E., 2011. Overpressure generation by load transfer following shale framework weakening due to smectite diagenesis. Geofluids 11, 362-375.

Lacoste, A., Vendeville, B.C., Loncke, L., 2011. Influence of combined incision and fluid overpressure on slope stability: experimental modelling and natural applications. Journal of Structural Geology 33, 731-742.

Lacoste, A., Vendeville, B.C., Mourgues, R., Loncke, L., Lebacq, M., 2012. Gravitational instabilities triggered by fluid overpressure and downslope incision e Insights from analytical and analogue modelling. Journal of Structural Geology 42, 151-162.

Mayorga, M.A., 1997. The pathology of primary blast overpressure injury. Toxicology 121, $17-28$.

Mazzarini, F., Isola, I., 2007. Hydraulic connection and fluid overpressure in upper crustal rocks: evidence from the geometry and spatial distribution of veins at Botrona quarry, southern Tuscany, Italy. Journal of Structural Geology 29, 1386-1399.

Mazzini, A., Nermoen, A., Krotkiewski, M., Podladchikov, Y., Planke, S., Svensen, H., 2009. Strike-slip faulting as a trigger mechanism for overpressure release through piercement structures. Implications for the Lusi mud volcano, Indonesia. Marine and Petroleum Geology 26, 1751-1765. 
Melnik, O., Barmina, A.A., Sparks, R.S.J., 2005. Dynamics of magma flow inside volcanic conduits with bubble overpressure buildup and gas loss through permeable magma, Journal of Volcanology and Geothermal Research 143, 53-68.

Morgenstern, N., 1962. A relation between hydraulic fracture pressures and tectonic stresses. Geofisica Pura e Applicata 52, 104-114.

Morrissey, M., Gisler, G., Weaver, R., Gittings, M., 2010. Numerical model of crater lake eruptions. Bulletin of Volcanology 72, 1169-1178.

Mourgues, R., Cobbold, P.R., 2006. Sandbox experiments on gravitational spreading and gliding in the presence of fluid overpressures. Journal of Structural Geology 28, 887901.

Mourgues, R., Costa, A.C.G., Marques, F.O., Lacoste, A., Hildenbrand, A., 2016. Structural consequences of cohesion in gravitational instabilities triggered by fluid overpressure: Analytical derivation and experimental testing. Journal of Structural Geology 87, 134143.

Pollard, D.D., Johnson, A.M., 1973. Mechanics of growth of some laccolithic intrusions in the Henry mountains, Utah, II. Bending and failure of overburden layers and sill formation. Tectonophysics 18, 311-354.

Potts, H.R., Pearson, G.L., 1966. Annealing and arsenic overpressure experiments on defects in gallium arsenide. Journal of Applied Physics 37, 2098.

Renshaw, C.E., Pollard, D.D., 1994. Are large differential stresses required for straight fracture propagation paths? Journal of Structural Geology 16, 817-822.

Robertson, A.B., 1972. Children, teachers and society: the over- pressure controversy, 18801886. British Journal of Educational Studies 20, 315-323.

Rubin, G.J., Burns, M., Wessely, S., 2014. Possible psychological mechanisms for "wind turbine syndrome". On the windmills of your mind. Noise and Health 16, 116-122. 
Sapozhnikov, O.A., Khokhlova, V.A., Bailey, M.R., Williams, J.C., McAteer, J.A., Cleveland, R.O., Crum, L.A., 2002. Effect of overpressure and pulse repetition frequency on cavitation in shock wave lithotripsy. The Journal of the Acoustical Society of America 112, 1183-1195.

Selig, E.T., McKee, K.E., Vey, E., 1960. Underground structures subject to air overpressure. Journal of the Engineering Mechanics Division 86, 87-104.

Shirzaei, M., Walter, T.R., Bürgmann, R., 2013. Coupling of Hawaiian volcanoes only during overpressure condition. Geophysical Research Letters 40, 1994-1999.

Sibson, R.H., 1990. Conditions for fault-valve behaviour. In: Knipe, R.J., Rutter, E.H. (eds), Deformation Mechanisms, Rheology and Tectonics. Geological Society, London, Special Publications 54, 15-28.

Sibson, R.H., 1992. Earthquake faulting, induced fluid flow, and fault-hosted gold-quartz mineralization. Proceedings of the International Conferences on Basement Tectonics 2, 603-614.

Sibson, R.H., 2004. Controls on maximum fluid overpressure defining conditions for mesozonal mineralisation. Journal of Structural Geology 26, 1127-1136.

Simpson, J.A., Weiner, E.S.C., 1989. Oxford English Dictionary, 2nd Edition. Clarendon Press, Oxford.

Stoneley, R., 1983. Fibrous calcite veins, overpressures and primary oil migration. American Association of Petroleum Geologists Bulletin 67, 1427-1428.

Suppe, J., 2014. Fluid overpressures and strength of the sedimentary upper crust. Journal of Structural Geology 69, 481-492.

Swarbrick, R.E., Lahann, R.W., 2016. Estimating pore fluid pressure-stress coupling. Marine and Petroleum Geology 78, 562-574. 
Swarbrick, R.E., Schneider, F., 1999. Introduction to special issue on overpressure research. Marine and Petroleum Geology 16, 301-302.

Tavarnelli, E., Holdsworth, R.E., Clegg, P., Jones, R.R., McCaffrey, J.W., 2004. The anatomy and evolution of a transpressional imbricate zone, Southern Uplands, Scotland. Journal of Structural Geology 26, 1341-1360.

Taras'ev, Y.I., Simkin, Y.D., 1969. Pressure-relief valve selection to match facility to be protected against overpressure. Chemical and Petroleum Engineering 5, 233-236.

Trasatti, E., Giunchia, C., Bonafede, M., 2005. Structural and rheological constraints on source depth and overpressure estimates at the Campi Flegrei caldera, Italy. Journal of Volcanology and Geothermal Research 144, 105-118.

van der Pluijm, B., Marshak, S., 2010. Earth Structure: an Introduction to Structural Geology and Tectonics. 2nd Edition. W.W. Norton and Co., New York, 656 pp.

Yardley, G.S., Swarbrick, R.E., 2000. Lateral transfer: a source of additional overpressure? Marine and Petroleum Geology 17, 523-537. 


\section{Highlights for "The interdisciplinary use of overpressure"}

- Overpressure is used in variety of different ways in the geosciences.

- We suggest that the term should be carefully defined whenever used.

- Other, less ambiguous terms could be used, such as supra-hydrostatic fluid pressure and supra-lithostatic fluid pressure. 